\section{COMPULSORY GREEK AT OXFORD AND CAMBRIDGE.}

THE statute enabling students of mathematics and natural science to proceed to a degree at Oxford, without previously passing in Greek, has been rejected in the larger house by 200 votes to 164 . At an earlier stage the proposal was adopted in the smaller assembly by the narrow majority of two votes. The discussion accorded to the statute was brief, for the voters had probably made up their minds; but it revealed the fact that, while the familiar arguments as to culture and the humanities held sway with those who have "learned nothing and forgotten nothing," some condemned the proposal, at least ostensibly, because it was too narrow. It would shut up school boys with a bent for mathematics or science to a "premature specialism," if they alone had to be segregated, years before the university stage, from their happier fellows on the "classical side."

The Cambridge proposals avoid at least this latter objection. They recognise that the examination which admits to the university should be one, in the sense that it allows the student who has passed it to enter any faculty or department of the university. He need not, while still at school, decide finally as to his special subject or subjects; and if he changes his mind as to the course he desires to pursue he need not retrace his steps, and begin to "get up " a new set of "little-go", subjects after he has entered the university. For three days high debate on the new scheme was held in the Cambridge Senate House, and so far as argument goes the impression produced is that the placets have the best of it. The official defenders of compulsory Greek spoke, naturally and properly, of the ennobling influence of Greek literature and philosophy. They scornfully derided the lack of culture disclosed by the false quantities of the mere man of science who is Greekless. But they failed to make clear the connection between the paltry rudiments, half grammar and half "crib," by which Greek is now represented in the previous examination, and humanistic culture or literary training of any sort. It was practically admitted that half the boys, even from classical schools of the straitest sect, might spend eight formative years over Greek and be no Hellenists in the end. But the conclusion was that time must be given for the improvement of school-teaching in classics, and that, in order to secure this improvement, the artificial support of the subject afforded by the present regulations is a necessity. The monopolists asked for more protection that they might mend their machinery.

One or two headmasters pleaded their helplessness before the uncultured parent if the shelter of academic compulsion were denied them, and the inconvenience they would suffer if they had to rearrange their timetables to make room for science and modern languages, with all their complexity. Greek for all who aspire to enter the university is so much simpler than French and German and science for some, mere " modern-siders," and Greek and Latin for others, the "pick of the school." "If compulsion is done away with, schools will soon give up Greek altogether; in ten years it will be as dead as Hebrew, "was the cry of these despairing headmasters. There were not wanting others to answer them, no less distinguished as scholars and teachers. The masters of Trinity and Christ's, the president of Queens' and Dr. Jackson, and other Grecians of established fame had such faith in the vitality of Greek-in its undying charm and its unrivalled power over the human spirit-that in their opinion it needed no such paltry prop to hold it upright. To force upon students of another bent the wasteful drudgery of six months' cramming in Greek accidence and the perfunctory conning of a set book with the help of a translation, was not only an educational blunder, but a grave moral wrong. It was bad for the student, it was bad for the master, it was bad for the university, and it was worst of all for the cause of Greek learning itself. It was breeding a race of students who, able and brilliant and influential in other paths, cherished a positive hostility to the distasteful subject that had raised itself as a needless obstacle in their way. But for compulsion they might have remained at worst indifferent, at best distant admirers of Greek. Now their only thought of it was associated with grievance and injustice. Times had changed, were changing fast; new methods of education were afoot in the schools. The bifurcation of studies-classical and nonscientific on the one hand, modern and scientific on the other-had become an accomplished fact. It was for the university frankly to recognise the change, and to give equal opportunity for both curricula. Cambridge had amply provided for the needs of the modern and scientific student once the barrier of the classical previous was passed. Why should the student, whose school and university course alike bore in one and the same direction, say towards natural science, be obliged to deviate during the last months of his school-time in order to pass through a wicket that lay straight in the path of his classical comrade, but far out of his own? True, a great teacher, a Porson or an Arnold or a Gow, might make even "Little-go Greek" a thing of life and light for his pupils; but what of the schools the head of which was a "mere Newton or Darwin "? Must the many be sacrificed for the few?

Then another issue was raised by the clerical members of the Senate, an issue on which, seeing the actual composition of the register, more will ultimately turn than on the educational question. If Greek is not compulsory, it will cease to be taught to and cease to be learned by candidates for ordination. The bishops of the Church of England will no longer be able to require a knowledge of the Greek Testament from the aspirant to holy orders.
It is admitted that the Presbyterian Church exacts both Greek and Hebrew as a condition of admission to its theological schools. But the heads of the Anglican Church are weaker than the General Assembly; the university must reinforce them, whatever the consequences to sound learning and unfettered research.

Grave warnings were uttered that the non possumus of the Senate on this question would not be the final word. Revolution, in other words a Royal Commission, would be the inevitable Nemesis of reform denied. And there is no doubt that this thought will weigh with some waverers, who love learning and fear for its displacement by modern studies, but who love the university more and dread the changes which a liberal government might impose on it from without.

The report of the syndicate will doubtless be referred back for reconsideration of details in the light of the discussion. But the principle that modern subjects shall be recognised will certainly be retained, and on this principle issue will be joined early next term. The result no man can predict, for it lies with the silent voters who will flock from the country to the poll. But the debate has cleared the air, and the reformers are sanguine that this time something will he done.

$$
\text { NO. } 1832 \text {, vOL. } 71 \text { \} }
$$

